\title{
Ore Microscopy of the Pegmatites of Keffi Area, North Central Nigeria
}

\author{
I. Y. Tanko and K. Dzigbodi-Adjimah
}

\section{ABSTRACT}

\begin{abstract}
Investigation of the pegmatites of Keffi area was carried out in reflected light microscopy to determine the texture, elemental composition, and the semi-quantitative analysis of the ore minerals from the three groups of pegmatites identified in Keffi area: the non-mineralised, the intermediate and the mineralised pegmatites. Backscattered Electron (BSE) images and Wavelength Dispersive Spectrometry (WDS) were used. Petrographically the portion which is characterised by profuse albitisation, sericitisation and silicification is also associated with the development of cleavelandite, lepidolite, coloured tourmaline and high concentrations of cassiterite and columbite-tantalite (coltan).The order of crystallisation in the pegmatites is from microcline to quartz followed by (plagioclases) oligoclase to albite and by mica (from biotite to muscovite) then by accessory minerals such as black tourmaline, garnet, beryl and lastly oxides of $\mathrm{Sn}-\mathrm{Nb}$-Ta. Sphene, rutile, zircon, apatite, ilmenite, and magnetite appeared to be earliest minerals whilst garnet pyrite and chalcopyrite may be syn-metamorphic. Beryl and coloured tourmaline appear to be of hydrothermal phase.
\end{abstract}

Keywords: Microscopy, mineralization, Ore, Pegmatites.
Published Online: September 30, 2021

ISSN: $2684-446 \mathrm{X}$

DOI : 10.24018/ejgeo.2021.2.5.174

I. Y. Tanko*

Department of Geology and Mining,

Nasarawa State University, Keffi, Nigeria.

(e-mail: iyantanko 2014@gmail.com) K. Dzigbodi-Adjimah

Department of Geological Engineering, University of Mines and Technology, Tarkwa, Ghana

${ }^{*}$ Corresponding Author

\section{INTRODUCTION}

Several woks have been reported on the occurrence of pegmatites and granites within gneisses and schistamphibolite host rocks in the Keffi area of North Central Nigeria [1], [2].

Apart from the numerous systematically worked pegmatite bodies, however, other pegmatite veins occur whose mineralogical characteristics and economic potential have not been investigated. As a result, small scale artisanal miners who work the deposits for cassiterite and tantalum indiscriminately exploit both the mineralised and barren pegmatite veins. The possibility of the presence of other economic minerals and/or gemstones in the veins has also not been investigated.

The importance of field, petrographic, mineralogical, and geochemical studies in resolving problems in pegmatite geology have been demonstrated in several studies e.g. [3][9]. It is therefore necessary to carry out petrological and mineralogical investigation on the pegmatites in order to assess their economic potential before mining.

This present work will focus on the petrography and the ore mineralogy of the pegmatites of Keffi area. It is also hope that the study would provide a guide to fruitful exploration of the deposits and any other deposits in similar geologic terrain.

\section{A. Regional Geology and Tectonic Setting}

Keffi lies within the Nigerian Basement Complex which forms part of the Pan African mobile belt. The Nigerian Basement Complex lies between the West African and Congo Cratons (Fig. 1) and south of the Tuareg shield [10]. The general geology of the Nigerian Basement Complex has been described by many authors e.g., [11]-[14]. The rocks are mainly granitoids, gneisses, schists and amphibolites. The country rocks have been petrologically identified as orthogneisses and pelitic schists-amphibolites.

The Nigerian Basement Complex of Nigeria is polycyclic in nature [13], [15] and [16] suggested that the Pan African mobile belt evolved by the collision between the passive continental margin of the West African craton and the active continental margin of the Tuareg shield about $600 \mathrm{Ma}$ ago. Reference [14] concluded that the belt has experienced deformation, thermal reactivation, metamorphism and emplacement of large volumes of granitoids (magmatism) typical of a Himalayan-type during the Pan African Orogeny $(600 \pm 150 \mathrm{Ma})$ ".

Generally, the basement rocks of Nigeria are believed to be the results of at least four major orogenic cycles [17], [12] and [18]. These cycles of deformation, metamorphism and remobilisation are:

The Liberian (Archaean) 2,700 Ma to $2750 \pm 25 \mathrm{Ma}$,

i. The Eburnean Orogeny (Early Proterozoic) 2,000 Ma to $2500 \mathrm{Ma}$, 


\section{ii. The Kibaran Orogeny (Mid Proterozoic) 1,100 Ma to} $2000 \mathrm{Ma}$, and

iii. The Pan African Orogeny (Palaeozoic) $600 \pm 150 \mathrm{Ma}$.

The first three cycles were characterised by intense deformation and isoclinal folding accompanied by regional metamorphism, which was further followed by extensive migmatisation, whilst the last cycle was characterised by deformation, metamorphism and granitisation. The closing stages of the orogeny were marked by cooling, uplift, fracturing, and by the intrusion of high level volcanic rocks [11], [12], [19].

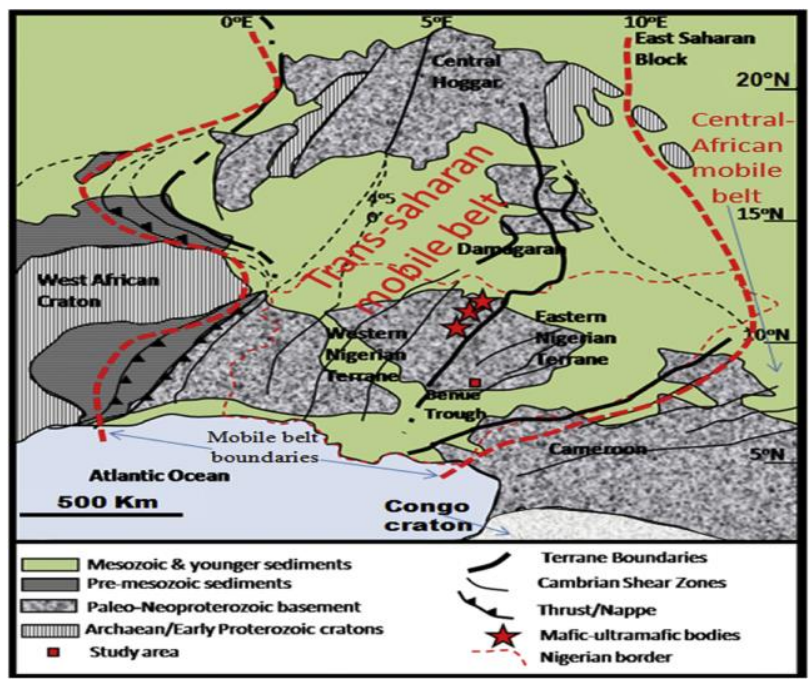

Fig. 1. Location of Nigeria in the Pan African Province of West Africa [20].

Major deformation involving folding and faulting together with fracturing and jointing are believed to have been reactivated or formed during the Pan African tectonic events of $600 \pm 150 \mathrm{Ma}$ [14]. Reference [19] believes that the regional metamorphism is mostly from upper greenschist facies to lower amphibolite facies, however, [21] is of the view that metamorphism actually reached an upper amphibolite facies. Reference [22] suggested 3 phases of metamorphism $\left(M_{1}, M_{2}\right.$ and $\mathrm{M}_{3}$ ) associated with the three phases of deformation that is recognised within the crystalline basement rocks. $M_{1}$ is believed to be asyntectonic progressive phase of metamorphism to amphibolite facies. $\mathrm{M}_{2}$ is a retrogressive metamorphism to greenschist facies whilst $\mathrm{M}_{3}$ is generally regarded as either being static or retrogressing earlier-formed garnet and biotite to chlorite".

The migmatites and schist of the earlier orogeneses were subjected to deformation during the later Pan African Orogeny and were intruded by the large masses of granitoids and associated undeformed felsic and mafic dykes of late Palaeozoic age. Thus, the belt, including the study area, lies in the reactivated region.

\section{GeOlogy of the Study AREA}

The Keffi pegmatite area is bounded by $8^{\circ} 40^{\prime} 00^{\prime \prime} \mathrm{N}$ and $8^{\circ}$ $50^{\prime} 10^{\prime \prime} \mathrm{N}$ and $7^{\circ} 50^{\prime} 00^{\prime \prime} \mathrm{E}$ and $8^{\circ} 02^{\prime} 00^{\prime \prime} \mathrm{E}$ and cover about $160.00 \mathrm{~km}^{2}$ (Fig. 1). Pegmatites of the Keffi area lie in what was first described by [1] as the "Pegmatite Belt of Central Nigeria". The belt belongs to the Pan African Granitoids unit of the north-central Basement Complex (Fig. 2). The rocks in the area consist of orthogneisses (granodiorite and augen granodiorite gneisses) and pelitic schists-amphibolites and their included granites and pegmatites. The main structural features in the area are the penetrative tectonic foliations trending mainly in the N-S, E-W, NE-SW and NW-SE directions.

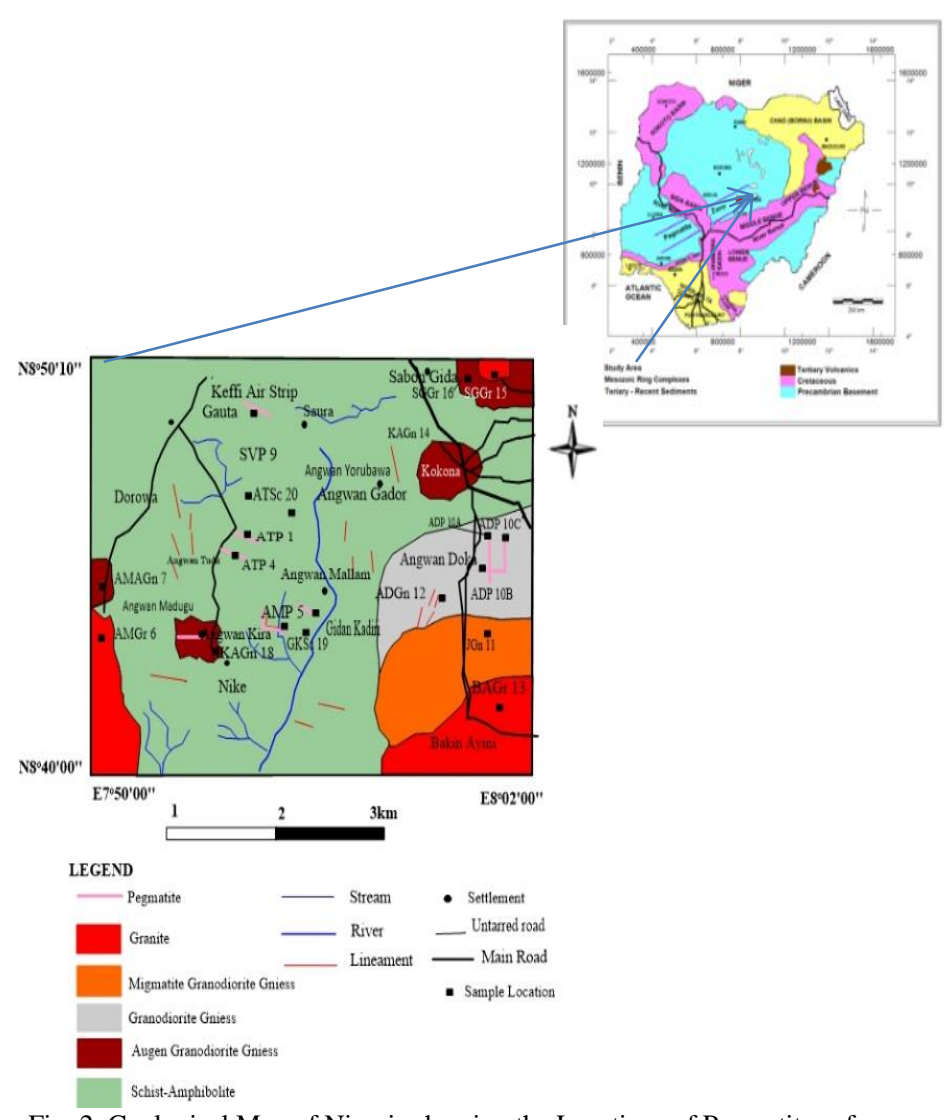

Fig. 2. Geological Map of Nigeria showing the Locations of Pegmatites of Central Nigeria and the Study Area [23].

\section{METHODOLOGY}

\section{A. Sampling}

Sampling of the pegmatites were carried out along profiles that start from the footwall, across the width of the veins into the hanging wall at 1 metre intervals. At the contacts between the veins and the country rocks, however, the sampling interval was reduced to $0.5 \mathrm{~m}$ and $0.25 \mathrm{~m}$ in order to monitor any changes that might occur at the contacts. Also, in order to relate field and thin section observations and deduce the order of crystallisation and make out any changes that may have occurred at the contacts. All the samples were oriented. The convention adopted was to mark the strike direction at the top of the sample and the dip sign at the southern face of the sample so that the actual orientation of the sample can be recreated during thin section preparation. Two thin sections were prepared from each sample, one along strike and the other along the dip.

Thin and polished sections were prepared in the Geological Engineering Department of University of Mines and Technology, Tarkwa Ghana. Modal compositions were determined using the point counter. The Scan Electron Microscopy (SEM) analysis and studies were conducted at the EPMA laboratory of Rhodes University, South Africa. 


\section{BRIEF FIELD AND PETROGRAPHIC OBSERVATIONS}

\section{A. The Pegmatites}

Summarily the field observations show that the pegmatite occur in association with other rock types like gneisses, granodiorites, granites and schistose-amphibolitic rocks. The contacts between the pegmatite and host rocks are observed to be sharp not gradational and lack any metamorphic or extensive metasomatic aureole [24].

Fresh samples of the pegmatites show interlocking, randomly oriented crystals of feldspars (microcline and plagioclase), quartz, micas (mostly muscovite), opaque minerals and other accessory minerals in varying proportion. Rod-like, prismatic crystals of varying colours of green, pink, red and black tourmaline (schorl) and grains of garnet of varying sizes occur in some outcrops. Based on the presence of cassiterite and columbite-tantailite (coltan) compositions of the pegmatites from hand-specimen and microscopic observations as presented in Table I, the pegmatites are classified into three groups as (i) Non Mineralised, (ii) Intermediate and (iii) Mineralised.

The classification is as follows:

i. Non mineralised Pegmatites: Angwan Mallam, Gidan Kadiri and Nike pegmatites;

ii. Intermediate: Angwan Tudu pegmatite;

iii.Mineralised: Angwan Doka and Saura pegmatites. A summary of the observations is presented in Table I.
TABLE I: MinERAL COMPOSITION OF THE PEGMATITES

\begin{tabular}{|c|c|c|c|}
\hline Minerals & $\begin{array}{c}\text { Nike } \\
\text { Pegmatite }\end{array}$ & $\begin{array}{c}\text { Angwan Tudu } \\
\text { Pegmatite }\end{array}$ & $\begin{array}{c}\text { Angwan Doka } \\
\text { Pegmatite }\end{array}$ \\
\hline \multicolumn{4}{|c|}{ Rock forming Minerals (Vol. \%) } \\
\hline Alkali feldspar & $30 \pm 5$ & $20 \pm 5$ & $22 \pm 5$ \\
\hline Plagioclase & $20 \pm 5$ & $15 \pm 5$ & $30 \pm 5$ \\
\hline Quartz & $25 \pm 5$ & $25 \pm 5$ & $15 \pm 5$ \\
\hline Biotite & $3 \pm 2$ & - & $2 \pm 1$ \\
\hline Chlorite & $0-2$ & - & $3 \pm 2$ \\
\hline Muscovite & $16 \pm 10$ & $15 \pm 5$ & $15 \pm 10$ \\
\hline Sericite & $0-3$ & $7 \pm 3$ & $15 \pm 10$ \\
\hline Hornblende & - & - & $0-2$ \\
\hline \multicolumn{4}{|c|}{ Accessory Minerals (vol. \%) } \\
\hline Apatite & - & - & 1.0 \\
\hline Beryl & - & - & $0-2$ \\
\hline Lepidolite & - & $0-10$ & $18 \pm 8$ \\
\hline Clevelandite & - & $?$ & $?$ \\
\hline Tourmaline & $3 \pm 2$ & $4 \pm 2$ & $3 \pm 2$ \\
\hline Garnet & $2 \pm 1$ & $3 \pm 2$ & $0-2$ \\
\hline Rutile & $5 \pm 1$ & $4 \pm 1$ & $1-3$ \\
\hline Sphene & - & - & - \\
\hline Zircon & - & - & $1-2$ \\
\hline
\end{tabular}

\section{ORE Mineralogy}

The Backscattered Electron (BSE) images and the Semiquantitative analysis of the opaque minerals from the Wavelength Dispersive Spectrometry (WDS) from the three groups of pegmatites are presented in this section.

\section{A. Non Mineralised pegmatites}

\section{1) Nike pegmatites}

The semi quantitative analysis shows that the ore mineral is ilmenite with $\mathrm{MnO}$ solid solution. The grain of ilmenite is surrounded by what is presumably younger quartz. Both the ilmenite grain and the enclosing quartz are fractured.

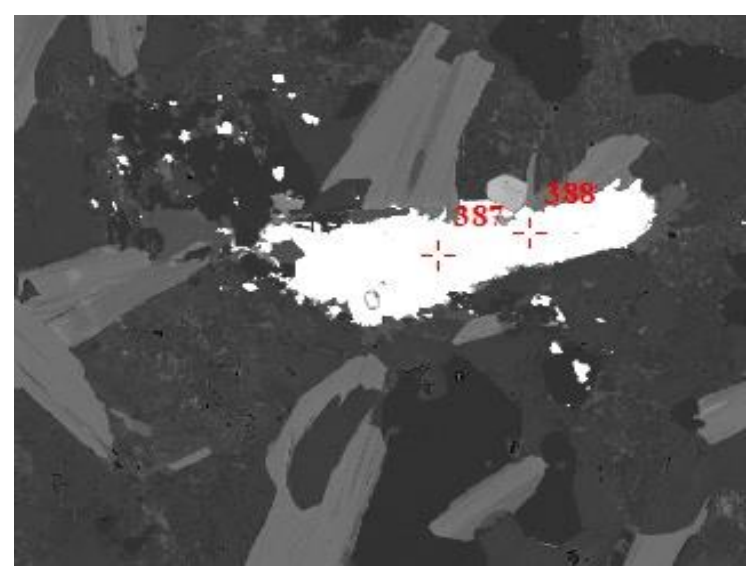

A

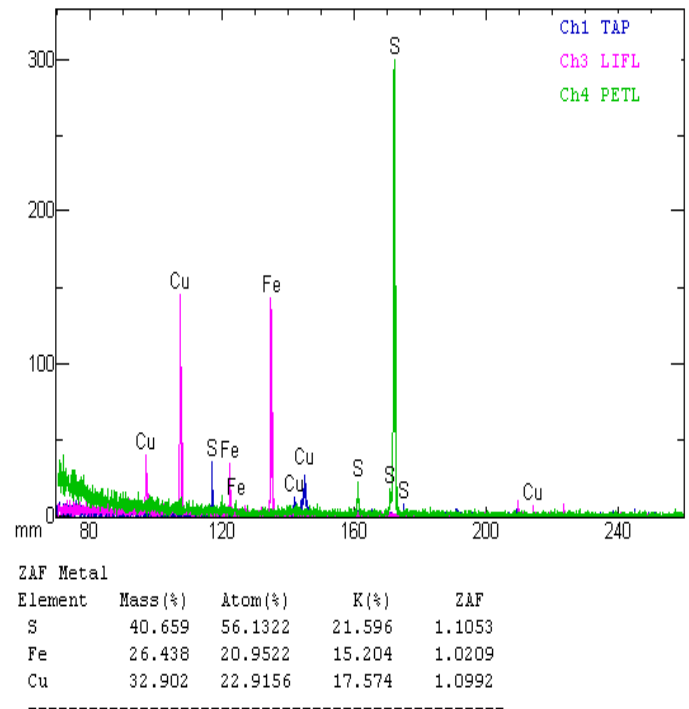

B

Fig. 3 A) BSE Image of ore minerals in Nike pegmatite showing an inclusion of Ilmenite in quartz gangue. B) A Plot of WDS of ore minerals in Nike pegmatite with the semi-quantitative analysis shows that the mineral is predominantly ilmenite.

\section{2) Gidan Kadiri pegmatites}

The opaque minerals found in these rocks are ilmenite, pyrite, chalcopyrite, and rutile as shown in Fig. 4 to 6 . No cassiterite or coltan was observed hence the polish section observations confirm the observation in hand-specimen and transmitted light that these pegmatites are devoid of Ta and $\mathrm{Sn}$.
The summary of the Classification and ore mineralisation potentials of the pegmatites is presented in Table II.

It appears from Table II that cassiterite and coltan mineralisation is commonly associated with zoning, this may not necessarily be the case all the times, some veins e.g., the Angwan Mallam (AMP 5) pegmatite is zoned but not mineralised whereas Angwan Tudu pegmatite (ADP10C) is unzoned but mineralised. 

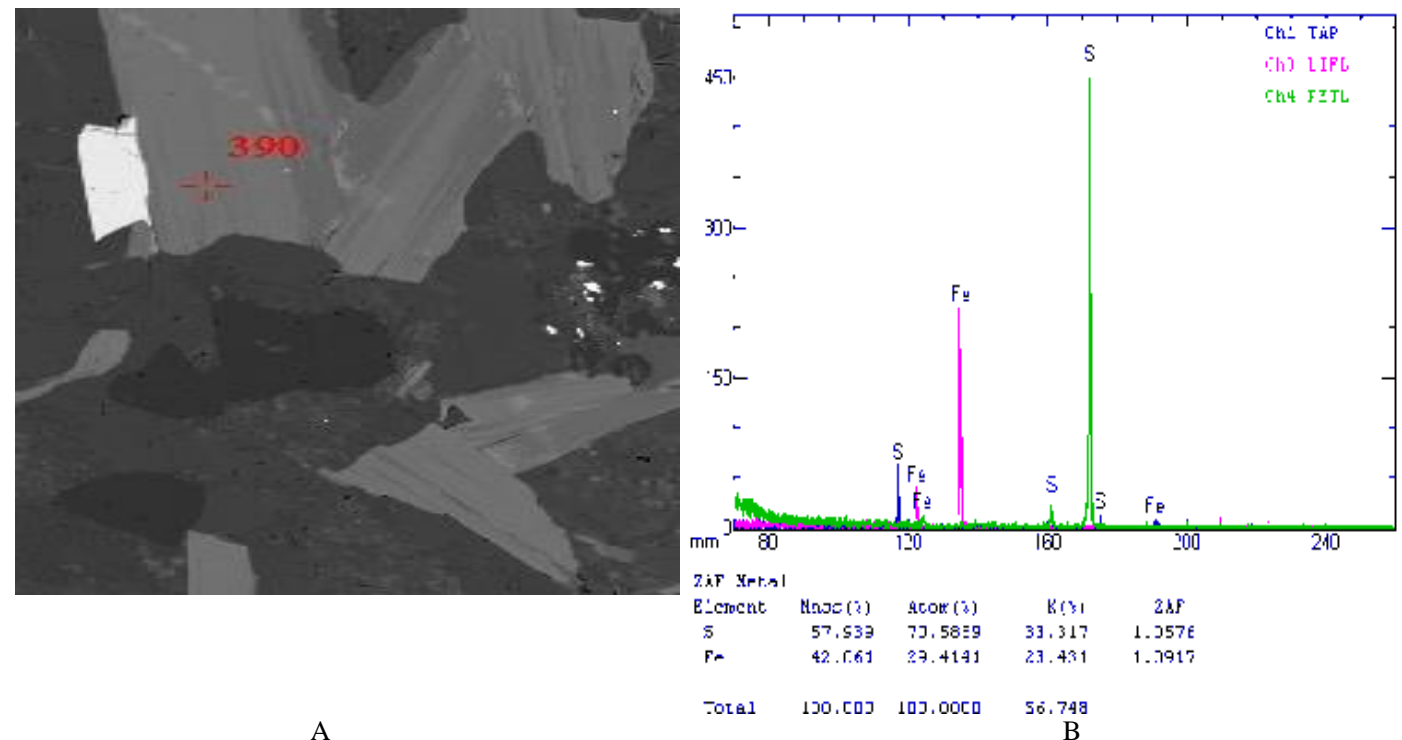

A

B) shows that the mineral composition is predominantly pyrite.
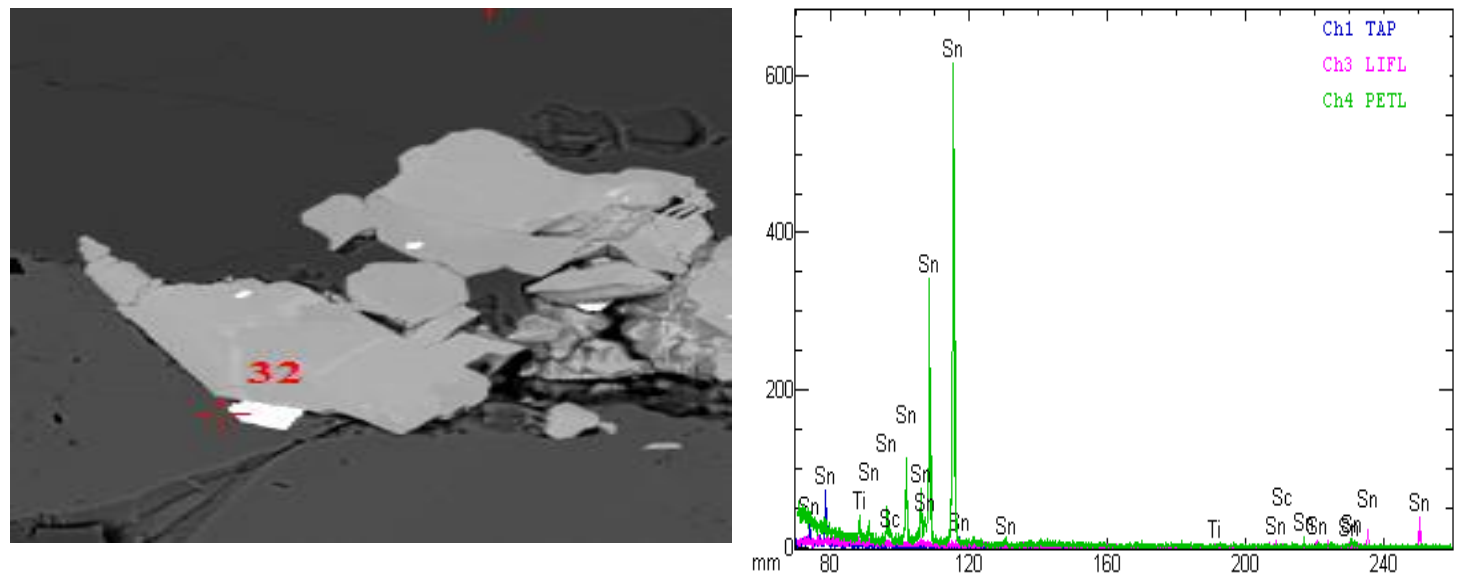

$\begin{array}{lrrrr}\text { ZAF Oxide } & & & & \\ \text { Element } & \text { Mass }(*) & \text { Cation } & \text { R(*) } & \text { ZAF } \\ \text { Sc203 } & 1.065 & 0.2728 & 1.246 & 1.0880 \\ \text { Ti02 } & 1.883 & 0.4163 & 2.088 & 1.1488 \\ \text { SnO2 } & 97.053 & 11.3791 & 113.826 & 1.0861\end{array}$

Fig. 5. BSE Image and WDS plot of ore minerals in Gidan Kadiri pegmatite. A) shows grains of a high reflecting sulphide in a matrix of randomly oriented feldspar and quartz. B) WDS analysis shows that the mineral composition is predominantly chalcopyrite

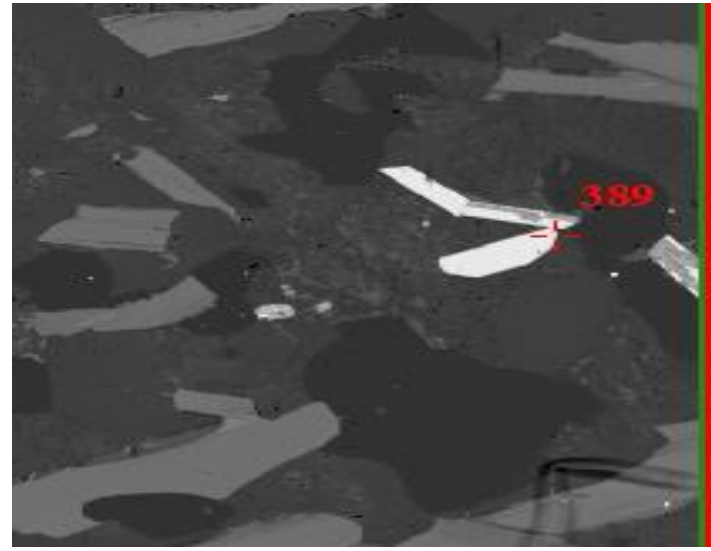

A

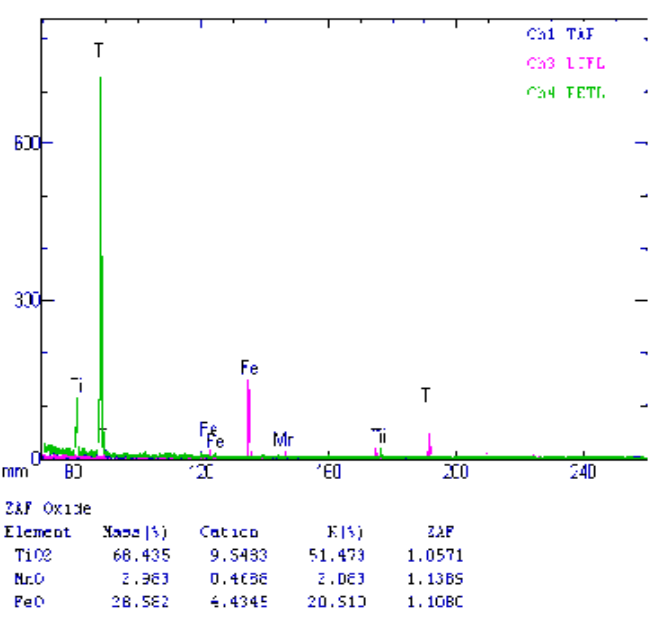

B

Fig. 6. BSE Image and WDS plot of ore minerals in Gidan Kadiri pegmatite. A) shows lenticular grains of medium reflecting oxides ilmenite (389) in a ground mass of randomly oriented laths of feldspar and anhedral quartz. B) the semi-quantitative display shows that the predominant ore is ilmenite. 


\section{B. Intermediate Pegmatites}

1) Angwan Tudu pegmatite
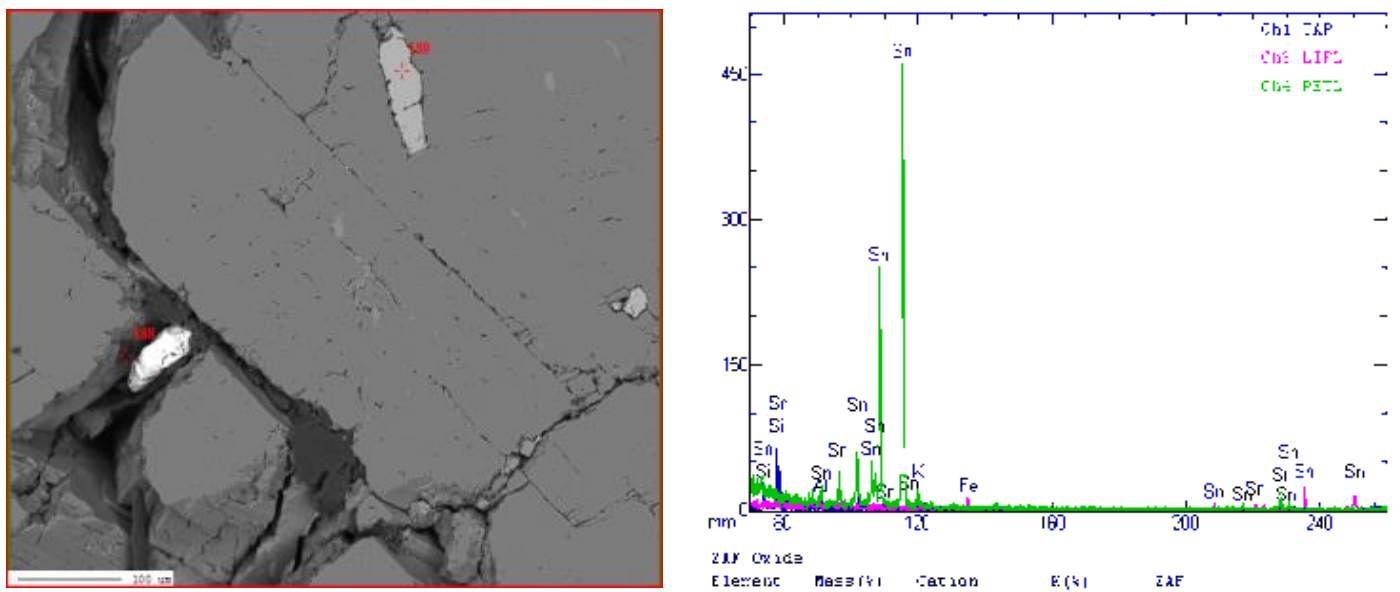

\section{2ur corice}

\begin{tabular}{|c|c|c|c|c|}
\hline $\begin{array}{l}\text { Elewelije } \\
5 x .: \bar{z}\end{array}$ & $\begin{array}{l}\text { nessiri } \\
10 C \cdot 000\end{array}$ & $\begin{array}{l}\text { "actzan } \\
1.00 כ 0\end{array}$ & $\begin{array}{r}E(\$ 1) \\
\text { a5.C64 }\end{array}$ & $\begin{array}{c}\bar{z} \lambda F \\
1.0 \approx 33\end{array}$ \\
\hline & $10 \mathrm{cc} .000$ & 1. Doכo & a5.CoA & \\
\hline
\end{tabular}

A

Fig. 7. BSE Image and WDS plot of ore minerals in Angwan Tudu Pegmatite 1. A) shows large grains of ilmenite occurring as inclusion in crystals of feldspar and anhedral quartz. B) is the semi-quantitative display of the mineral which indicate ilmenite as the dominant ore mineral.
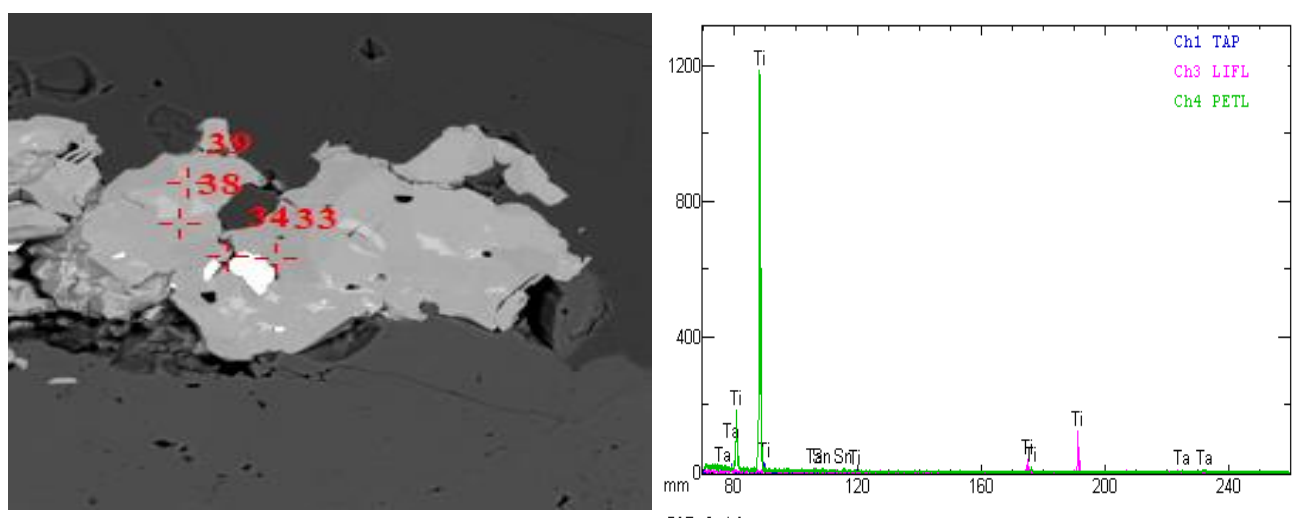

Zha Oxide

$\begin{array}{lrrrr}\text { 2AF Oxide } & & & & \\ \text { Element } & \text { Mass (\%) } & \text { Cation } & \mathrm{K}(\xi) & \text { Z.AF } \\ \text { Ti02 } & 93.169 & 11.5932 & 82.000 & 1.0819 \\ \text { Sn02 } & 2.325 & 0.1534 & 2.012 & 1.1002 \\ \text { Ta205 } & 4.505 & 0.2027 & 2.968 & 1.4456\end{array}$

A

B

Fig. 8. BSE Image and WDS plot of ore minerals in Angwan Tudu pegmatite 1. A) shows ore minerals as inclusions in silicates. It consists of cassiterite $(33,34)$, rutile (38), and tantalite (39). B) is the semi-quantitative display of the WDS analyses.

\section{Mineralised Pegmatites}

\section{1) Angwan Doka pegmatite}
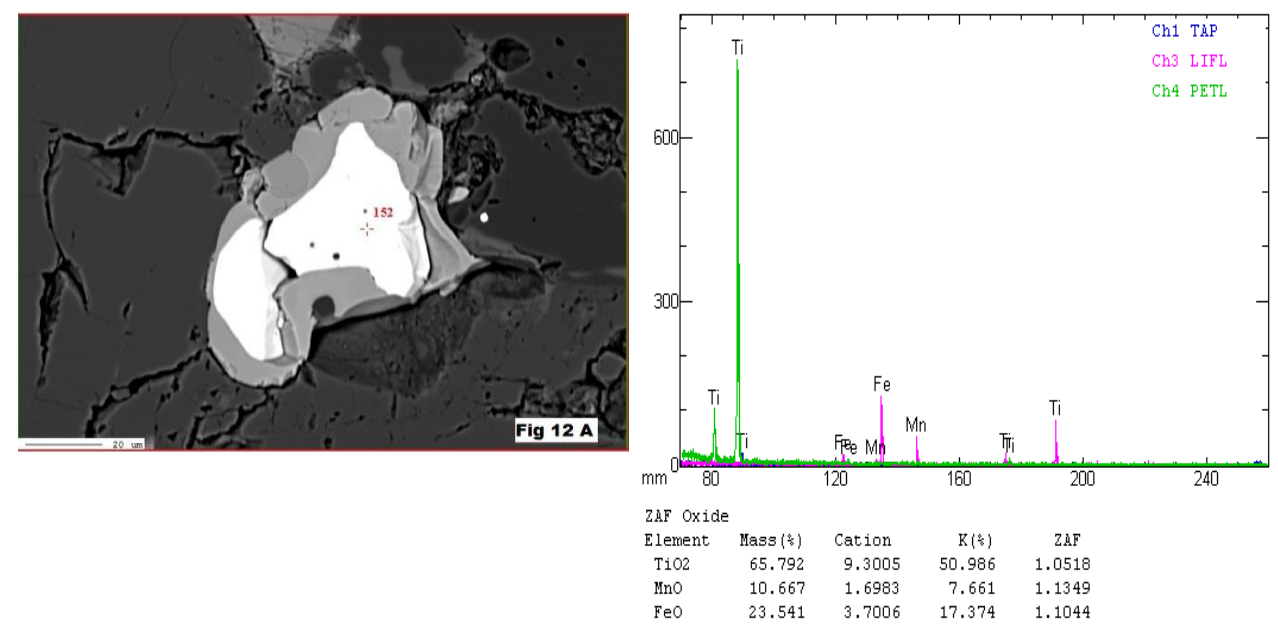

A

B

Fig. 9. BSE Image and WDS plot of ore minerals in Angwan Doka Pegmatite (Sample (ADP10C d). A) shows that the cassiterite (188) is located between grain boundaries whilst the apatite (189) is an inclusion within feldspar. B) the semi-quantitative display of the WDS analysis indicates cassiterite as the dominant ore mineral. 


\section{2) Saura pegmatite}
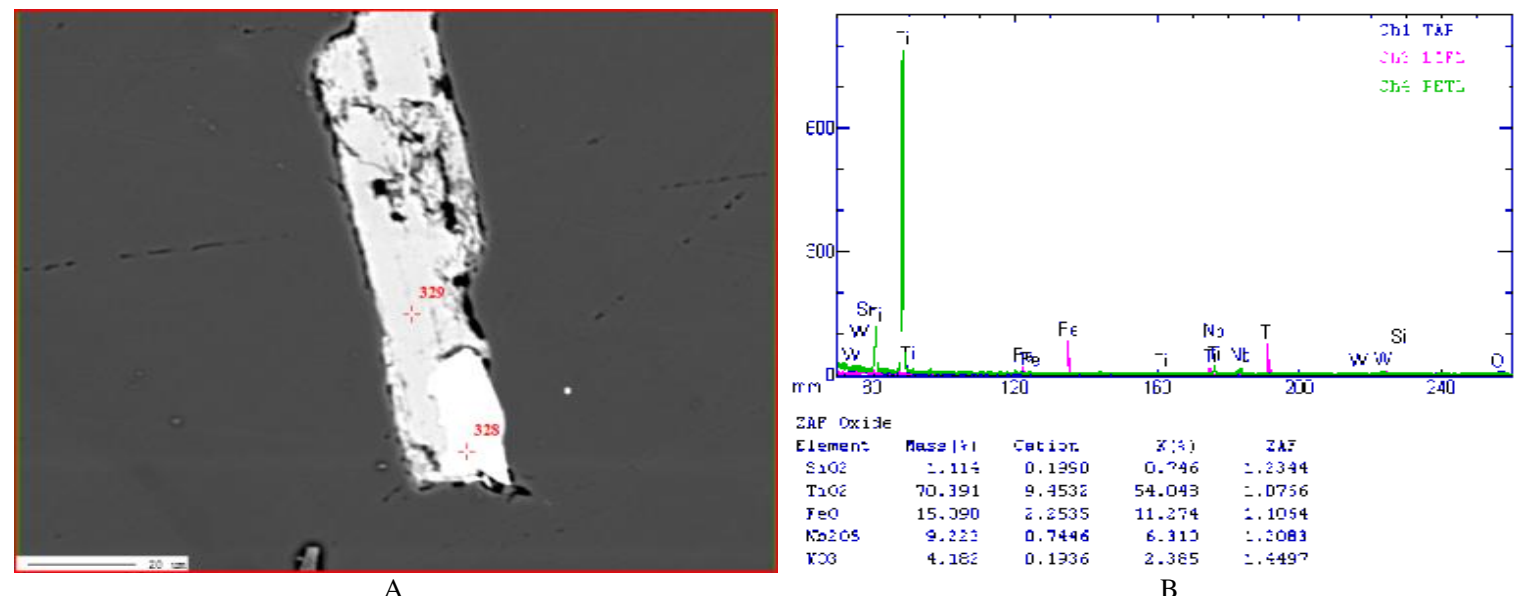

Fig. 10. BSE images and WDS plot of sample (SVP 9 c) from Saura Village pegmatite 9. A) shows columbite (233) and zircon (234) and (235) grains. B) shows their semi-quantitative analyses.
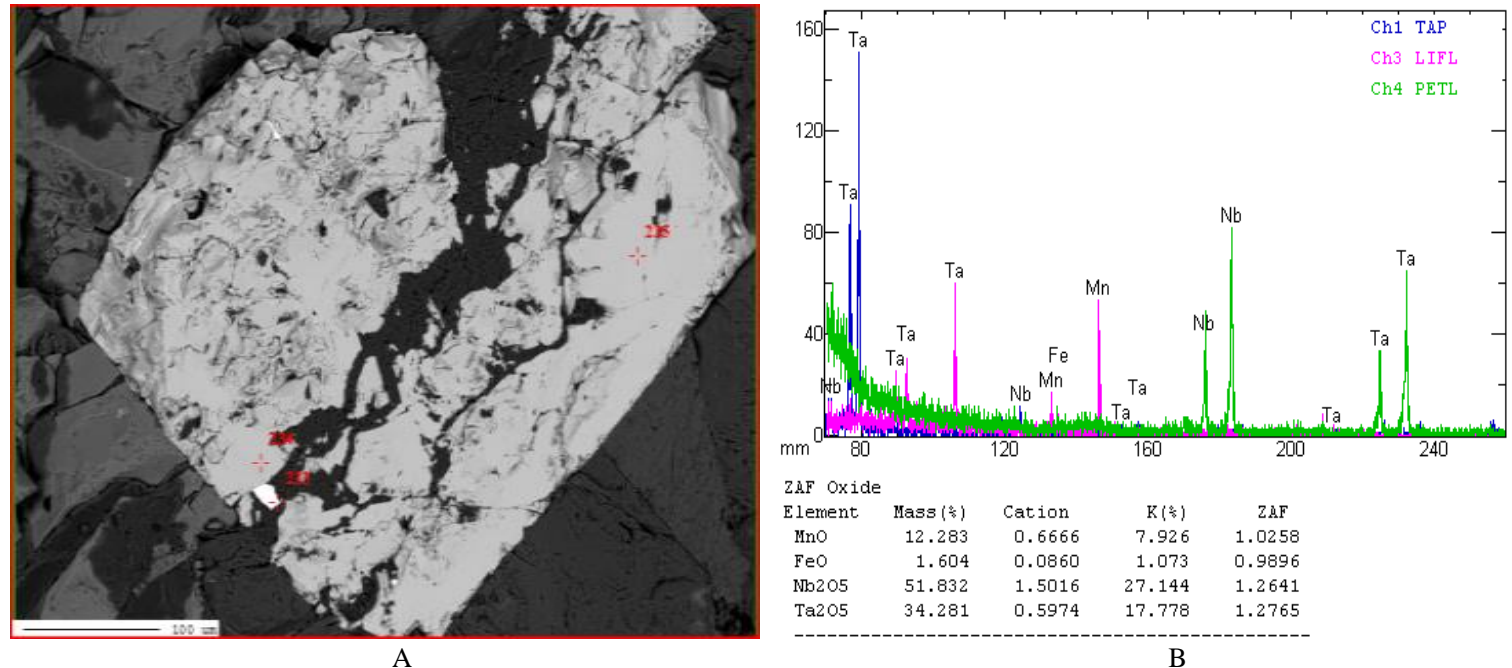

Fig. 11. BSE images and WDS plot of sample.

(SVP 9 c) from Saura Village pegmatite 9. A) contains ilmenite (328) columbite - wolframite (329). B) shows their semi-quantitative analyses.

\begin{tabular}{|c|c|c|c|}
\hline $\begin{array}{l}\text { Sample } \\
\text { No. }\end{array}$ & Name & Ore minerals & Economic/zoning Status \\
\hline GKP8 & Gidan Kadiri & $\begin{array}{c}\text { Pyrite, } \\
\text { chalcopyrite, } \\
\text { ilmenite }\end{array}$ & $\begin{array}{l}\text { Non-mineralised/ } \\
\text { (unzoned) }\end{array}$ \\
\hline AMP5 & $\begin{array}{l}\text { Angwan } \\
\text { Mallam }\end{array}$ & Schorl and beryl & $\begin{array}{l}\text { Non-mineralised/ } \\
\text { (zoned) }\end{array}$ \\
\hline ATP1 & $\begin{array}{l}\text { Angwan } \\
\text { Tudu }\end{array}$ & $\begin{array}{l}\text { Zircon, rutile } \\
\text { minor cassiterite } \\
\& \text { tantalite }\end{array}$ & Intermediate / (zoned) \\
\hline ATP4 & AngwanTudu & $\begin{array}{l}\text { Zircon, rutile } \\
\text { Minor } \\
\text { cassiterite \& } \\
\text { tantalite }\end{array}$ & Intermediate/ (zoned) \\
\hline SVP 9 & Saura Village & $\begin{array}{l}\text { Cassiterite, } \\
\text { lepidolite, } \\
\text { apatite, } \\
\text { tourmaline }\end{array}$ & Mineralised/ (zoned) \\
\hline ADP10A & $\begin{array}{l}\text { Angwan } \\
\text { Doka }\end{array}$ & $\begin{array}{l}\text { Cassiterite, } \\
\text { lepidolite, } \\
\text { apatite, } \\
\text { tourmaline }\end{array}$ & Mineralised/ (unzoned) \\
\hline ADP10B & $\begin{array}{l}\text { Angwan } \\
\text { Doka }\end{array}$ & $\begin{array}{l}\text { Cassiterite, } \\
\text { lepidolite, } \\
\text { apatite, } \\
\text { tourmaline }\end{array}$ & Mineralised/(zoned) \\
\hline ADP10C & $\begin{array}{l}\text { Angwan } \\
\text { Doka }\end{array}$ & $\begin{array}{l}\text { Cassiterite, } \\
\text { lepidolite, } \\
\text { apatite, } \\
\text { tourmaline }\end{array}$ & Mineralised/ (unzoned) \\
\hline NKP17 & $\begin{array}{c}\text { Nike } \\
\text { pegmatite }\end{array}$ & $\begin{array}{l}\text { Ilmenite, } \\
\text { magnetite, }\end{array}$ & $\begin{array}{c}\text { Non-mineralised/ } \\
\text { unzoned }\end{array}$ \\
\hline
\end{tabular}

\section{DISCUSSION}

\section{A. Ore Mineralisation}

The polished sections show the paragenetic sequence of ore formation. It shows that accessory minerals are older than the oxides which in turn are older than the sulphides. Sulphide mineralisation is the youngest of the opaque minerals. Quartz is of two generations, namely an early crystallisation paragenesis and a younger hydrothermal phase which appears to be the youngest in the paragenesis. Fig. 3 A shows secondary quartz forming around a grain of ilmenite which shows that the quartz is younger. Both the ilmenite grain and the enclosing quartz are fractured indicating that deformation continued after the hydrothermal mineralising phase. Figs. 3 A, 4 A \& 6 B show ilmenite, pyrite and chalcopyrite growing across earlier formed silicates which attest to their younger, probably metamorphic age. Fig. 9 A shows that cassiterite is late mineral that forms at the contact of earlier formed silicates and is normally at grain boundaries whereas rutile and tantalite are old and occur as inclusions in silicates (Fig. 8). Fig $10 \mathrm{~A}$ shows zircon as an inclusion in silicate indicating that it is an early-formed mineral. Figs. 13(A \& B) show that apatite is an early formed mineral which is included in later formed silicates but the cassiterite grain is again seen as a 
much younger mineral which is located in fractures or at grain boundaries. The summary of paragenetic observations is presented in Table III.

TABLE III: GENERALISED Mineral PARAGENESIS OF THE PEGMATITES OF KEFFI AREA

\begin{tabular}{|c|c|}
\hline \multirow[b]{2}{*}{ Mineral } & Early stage (primary) $\longrightarrow$ Late stage(Secondary) \\
\hline & $\begin{array}{ccc}\text { Border zone } & \begin{array}{c}\text { Intermediate } \\
\text { zone }\end{array} & \begin{array}{c}\text { Coarsequartz } \\
\text { /Centra zone }\end{array} \\
\end{array}$ \\
\hline \multicolumn{2}{|l|}{ Alkali feldspar } \\
\hline \multicolumn{2}{|l|}{ Plagioclase } \\
\hline \multicolumn{2}{|l|}{ feldspar } \\
\hline \multicolumn{2}{|l|}{ Biotite } \\
\hline \multicolumn{2}{|l|}{ Muscovite } \\
\hline \multicolumn{2}{|l|}{ Chlorite } \\
\hline \multicolumn{2}{|l|}{ Sericite } \\
\hline \multicolumn{2}{|l|}{ Lepidolite } \\
\hline \multicolumn{2}{|l|}{ Tourmaline } \\
\hline \multicolumn{2}{|r|}{ 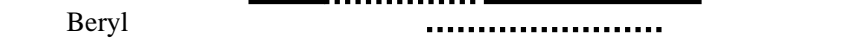 } \\
\hline \multicolumn{2}{|l|}{ Garnet } \\
\hline \multicolumn{2}{|l|}{ Apatite } \\
\hline \multicolumn{2}{|r|}{...................... } \\
\hline \multicolumn{2}{|l|}{ Rutile } \\
\hline \multicolumn{2}{|l|}{ Ilmenite } \\
\hline \multicolumn{2}{|l|}{ Sulfides } \\
\hline \multicolumn{2}{|l|}{ Cassiterite } \\
\hline Columbo-tantalite & 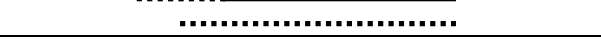 \\
\hline
\end{tabular}

\section{CONCLUSIONS}

From the above discussions the following conclusions may be made:

(1) The rocks in the area consist of orthogneisses (granodiorite and augen granodiorite gneisses) and pelitic schists-amphibolites and their included granites and pegmatites. Petrographically the portion, which is characterised by profuse albitisation, sericitisation and silicification is also associated with the development of cleavelandite, lepidolite, coloured tourmaline and high concentrations of cassiterite and columbitetantalite (coltan). Hence these areas should be targeted during mineral exploitation.

(2) The order of crystallisation in the pegmatites is from microcline to quartz followed by (plagioclases) oligoclase to albite and by micas (from biotite to muscovite) then by accessory minerals such as black tourmaline, garnet, beryl and lastly oxides of $\mathrm{Sn}-\mathrm{Nb}$ Ta. Sphene and rutile zircon, apatite, ilmenite, and magnetite appear to be earliest minerals whilst garnet pyrite and chalcopyrite may be syn-metamorphic. Beryl and coloured tourmaline appear to be of hydrothermal phase.

\section{ACKNOWLEDGMENT}

The authors thank the Tertiary Education Trust Fund and Nasarawa State University Keffi, Nasarawa State Nigeria which sponsored this research work. We wish to also express our appreciation to the Geological Engineering Department, University of Mines and Technology, Tarkwa Ghana for the use of their laboratory for sample preparation.

\section{REFERENCES}

[1] R. Jacobson and J. S. Webb, "The Pegmatite of Central Nigeria", Geological Survey of Nigeria Bulletin, Vol. 17, pp. 61, 1946.

[2] D. Kuster "Rare-Metal Pegmatites of Wamba, Central Nigeria-their Formation in Relationship to Late Pan-African Granites", Mineral Deposita, Vol. 25, pp. 25-33, 1990.

[3] A. I., Ginsburg, I. N. Timofeyev, and L. G. Feldman, Principles of Geology of the Granitic Pegmatites, Nedra, Moscow, Russia, pp. 296, 1979.

[4] P. Cerny Petrogenesis of Granitic Pegmatites, In Mineralogical Association of Canada, Short Course Handbook, No. 8, Granitic Pegmatites in Science and Industry, 1982, pp. 405-461.

[5] R. A., Crouse, P. Cerny, D. L. Trueman, and R. O. Burt, "The Tanco Pegmatite, Southeastern Manitoba”, In CIM Special, Vol. 29, The Geology of Industrial Minerals in Canada, pp. 169-176, 1984.

[6] G. B. Morgan VI., D. London, "Alteration of Amphibolitic Wall rocks Aroundthe Tanco Rare-Element Pegmatite", Bernic Lake Manitoba, Am. Mineral., Vol. 72, pp. 1097-1121, 1987.

[7] P. Cerny, "Rare-Element Granitc Pegmatites, Part I: Anatomy and Internal Evolution of Pegmatite Deposits", Geoscience Can., Vol. 18, pp. 49-67, 1991.

[8] D. London, "The Application of Experimental Petrology to the Genesis and Crystallisation of Granitic Pegmatites", Can. Mineral, Vol. 30, pp. 499-540, 1992.

[9] P. Cerny and T. S. Ercit and P. T Vanstone, "Petrology and Mineralisation of the Tanco Rare-Element Pegmatite, South-eastern Manitoba-Field Trip Guidebook A4, Geol. Ass. Can. Annual Meeting, Winnipeg Manitoba, 63 pp, 1996.

[10] R. Black. "Precambrian of West Africa", Episodes, No. 4, pp. 3, 1980,

[11] H. A. Jones, and R. D. Hockey (1964), "The Geology of Part of South Western Nigeria”, Geol. Surv. Nigeria Bull. No. 31, pp. 101, 1980.

[12] M. A. Rahaman, "Review of Basement Geology of Southern Nigeria, In Kogbe", C. A. (Eds.), Geol. Nigeria Elizabethan press, Lagos, Nigeria, 1976, pp. 41-58.

[13] A. C. Ajibade, M. Woakes, and M. A. Rahaman, "Proterozoic Crustal Development in the Pan-African Regime of Nigeria", In C. A. Kogbe (Eds.), Geol. Nigeria, $2^{\text {nd }}$ Revised Eds., Elizabethan Publ., Lagos, 1989, pp. 57-69.

[14] S. S. Dada, "Proterozoic Evolution of Nigeria", In: The Basement Complex of Nigeria and its Mineral Resources (Oshin O. ed.), A Symposium organized to mark the 60th birthday of Prof. M. A. O. Rahaman, held at the Conference Centre, Obafemi Awolowo University, Ile - Ife, Nigeria, May 6th 2006, pp. 29-44.

[15] K. C. Burke and J. F. Dewey, "Orogeny in Africa." In: Dessauvagie, T.F.J. and Whiteman, A. J. (Eds.), African Geology, University of Ibadan Press, Ibadan, 1972, pp. 583-608.

[16] R., Caby, J. M. L Brand and R Black, Pan-African Ocean Closure and continental Collision in the Hoggar Iforas Segment, Central Sahara", in Precambrian Tectonics", Edited by a Kroner, Elsevier Amsterdam, 1981, pp. 407-434

[17] P. McCurry, "The Geology of the Precambrian to Lower Paleozoic Rocks of Northern Nigeria - A Review", Geology of Nigeria., Elizabethan Publ. Co., Lagos, 1976, pp.15-40.

[18] J. B. Wright, "Fracture Systems in Nigeria and Initiation of Fracture Zones in the South Atlantic", Tectonophysics, Vol. 34, pp. 743-747, 1976.

[19] M. A. Rahaman, "Recent Advances in the Study of the Basement Complex of Nigeria", Precambrian Geol. Nigeria, Geol. Surv. Nig. Pub., 1988, pp. 324-327.

[20] E. Ferre, R., Caby, J. J., Peucatt, R Capdevila, and P. Monie, Pan-Africa post collisional ferro-potassic granite and quartz-monzonite plutons of Eastern Nigeria. Lithos, 45, pp. 255-278, 1998.

[21] A. O. Oyinloye, Geology and Geotectonic Setting of the Basement Complex rocks in southwestern Nigeria: Implications on Provenance and Evolution.Earth and Environmental Sciences, pp. 45-78, 2011.

[22] B. N. Ekwueme, 'Regional metamorphism of pelitic rocks, south-east of Lokoja, Nigeria.Nigerian journal of Min. Geol. Vol. 20, pp. 17-24, 1983.

[23] J. A. Kinnaird, "Contrasting Styles of Sn-Nb-Ta-Zn Mineralisation in Nigeria" Journal of African Earth. Science Vol. 2, No. 2, pp. 81-90, 1984.

[24] I.Y. Tanko, M. Adam and P.D. Dambring, "Field Features and Mode of Emplacement of Pegmatites of Keffi Area, North Central Nigeria”. International Journal of Scientific \& Technology Research Vol. 4, pp. 214-229, 2015. 